University of Nebraska - Lincoln

DigitalCommons@University of Nebraska - Lincoln

Faculty Publications from the Harold W. Manter Laboratory of Parasitology

2002

\title{
Protostrongylus stilesi (Nematoda: Protostrongylidae): Ecological Isolation and Putative Host-Switching Between Dall's Sheep and Muskoxen in a Contact Zone
}

\author{
Eric P. Hoberg \\ United States Department of Agriculture, Agricultural Research Service, geocolonizer@gmail.com \\ Susan J. Kutz \\ University of Saskatchewan \\ John Nagy \\ Government of the Northwest Territories \\ Emily Jenkins \\ University of Saskatchewan \\ Brett Elkin \\ Government of the Northwest Territories \\ See nextpage for additional authors \\ Part of the Biodiversity Commons, Parasitology Commons, and the Terrestrial and Aquatic Ecology \\ Commons
}

Hoberg, Eric P.; Kutz, Susan J.; Nagy, John; Jenkins, Emily; Elkin, Brett; Branigan, Marsha; and Cooley, Dorothy, "Protostrongylus stilesi (Nematoda: Protostrongylidae): Ecological Isolation and Putative HostSwitching Between Dall's Sheep and Muskoxen in a Contact Zone" (2002). Faculty Publications from the Harold W. Manter Laboratory of Parasitology. 663.

https://digitalcommons.unl.edu/parasitologyfacpubs/663

This Article is brought to you for free and open access by the Parasitology, Harold W. Manter Laboratory of at DigitalCommons@University of Nebraska - Lincoln. It has been accepted for inclusion in Faculty Publications from the Harold W. Manter Laboratory of Parasitology by an authorized administrator of DigitalCommons@University of Nebraska - Lincoln. 


\section{Authors}

Eric P. Hoberg, Susan J. Kutz, John Nagy, Emily Jenkins, Brett Elkin, Marsha Branigan, and Dorothy Cooley 


\title{
Protostrongylus stilesi (Nematoda: Protostrongylidae): Ecological Isolation and Putative Host-Switching Between Dall's Sheep and Muskoxen in a Contact Zone
}

\author{
Eric P. Hoberg, ${ }^{1,6}$ Susan J. Kutz, ${ }^{2}$ John Nagy, ${ }^{3}$ Emily Jenkins, ${ }^{2}$ Brett Elkin, ${ }^{4}$ \\ Marsha Branigan, ${ }^{3}$ AND Dorothy COOLEY ${ }^{5}$ \\ ${ }^{1}$ Biosystematics Unit of the Parasite Biology, Epidemiology and Systematics Laboratory, United States \\ Department of Agriculture, Agricultural Research Service, BARC East No. 1180, Beltsville, Maryland 20705, \\ U.S.A. (e-mail: ehoberg@anri.barc.usda.gov), \\ ${ }^{2}$ Department of Veterinary Microbiology, Western College of Veterinary Medicine, 52 Campus Drive, \\ University of Saskatchewan, Saskatoon, Saskatchewan, Canada S7N 5B4, \\ ${ }^{3}$ Department of Resources, Wildlife and Economic Development, Government of the Northwest Territories, \\ P.O. Box Bag 1, Inuvik, Northwest Territories, Canada X0E 0T0, \\ ${ }^{4}$ Department of Resources, Wildlife and Economic Development, Government of the Northwest Territories, \\ Wildlife Health Program, Wildlife and Fisheries Division, 600 5102-50th Avenue, Yellowknife, Northwest \\ Territories, Canada X1A 3S8, and \\ ${ }^{5}$ Regional Biologist, Box 600, Dawson City, Yukon Territory, Canada Y0B 1G0
}

\begin{abstract}
The occurrence of Protostrongylus stilesi in a population of introduced muskoxen, Ovibos moschatus wardi, on the Arctic Coastal Plain, Yukon Territory (YT) and Northwest Territories (NT), Canada, is consistent with a contemporary colonization event from Dall's sheep, Ovis dalli dalli, which indicates that host specificity may be ecologically based and contextual for this parasite. Colonization of muskoxen by $P$. stilesi may be a predictable event in zones of sympatry with Dall's sheep; exposure to infection may coincide with occupation of winter ranges of Dall's sheep by muskoxen during the summer season. Disruption of contemporary ecological isolating barriers can result from anthropogenically or climatologically driven habitat perturbation, and result from management practices that influence the distribution of ungulate hosts. Thus, if zones of contact become more extensive or the temporal limits on allopatry are relaxed, we may observe increasing instances of host switching by parasites or pathogens at the interface of newly emerging ecotones. Impacts to northern systems linked to climatologically and anthropogenically driven global change and the effects of management must be tracked within the context of biodiversity survey and inventory and archival collections, as foundations for monitoring ecosystem-level perturbations. A developing interface for muskoxen, wild sheep, and parasites along the Mackenzie River ecotone represents a natural model or field laboratory to examine these processes. Additonally, lungworms, Protostrongylus spp., had not been reported in muskoxen, and a new geographic record for this nematode was established in Dall's sheep from the northern Richardson Mountains, NT.

KEY WORDS: Protostrongylus stilesi, muskoxen, Dall's sheep, ecological isolation, colonization, biodiversity survey, Northwest Territories, Yukon Territory, Canada.
\end{abstract}

Knowledge of the diversity and biogeography of lungworm faunas (Protostrongylidae) among northern species of Bovidae has dramatically increased with a series of recent studies (Hoberg et al., 1995; Kutz, Hoberg, and Polley, 2001; Kutz, Veitch et al., 2001). Among Caprinae, including Dall's sheep Ovis dalli Nelson, 1884, and muskoxen Ovibos moschatus (Zimmermann, 1780), at high latitudes across the Nearctic, this nematode fauna appears to be characterized by limited diversity. A few species, however, may be widely distributed, and current records have served to establish recognition of a broad geographic range

\footnotetext{
${ }^{6}$ Corresponding author.
}

for Protostrongylus stilesi Dikmans, 1931, in the western Nearctic among populations of $O$. dalli in the Subarctic and Arctic and in bighorn sheep Ovis canadensis Shaw, 1804, at boreal latitudes (see Kutz, Veitch et al., 2001).

In contrast to the protostrongyle fauna in wild sheep, lungworms are uncommon parasites in both native and introduced populations of muskoxen throughout their current range in the Holarctic (Alendal and Helle, 1983; Hoberg et al., 1995). On the mainland of North America, 2 subspecies of muskoxen are now present (Fig. 1): (1) the native $O$. moschatus moschatus (Zimmermann, 1780), which has a distribution across the central Canadian Arctic; and (2) the introduced 


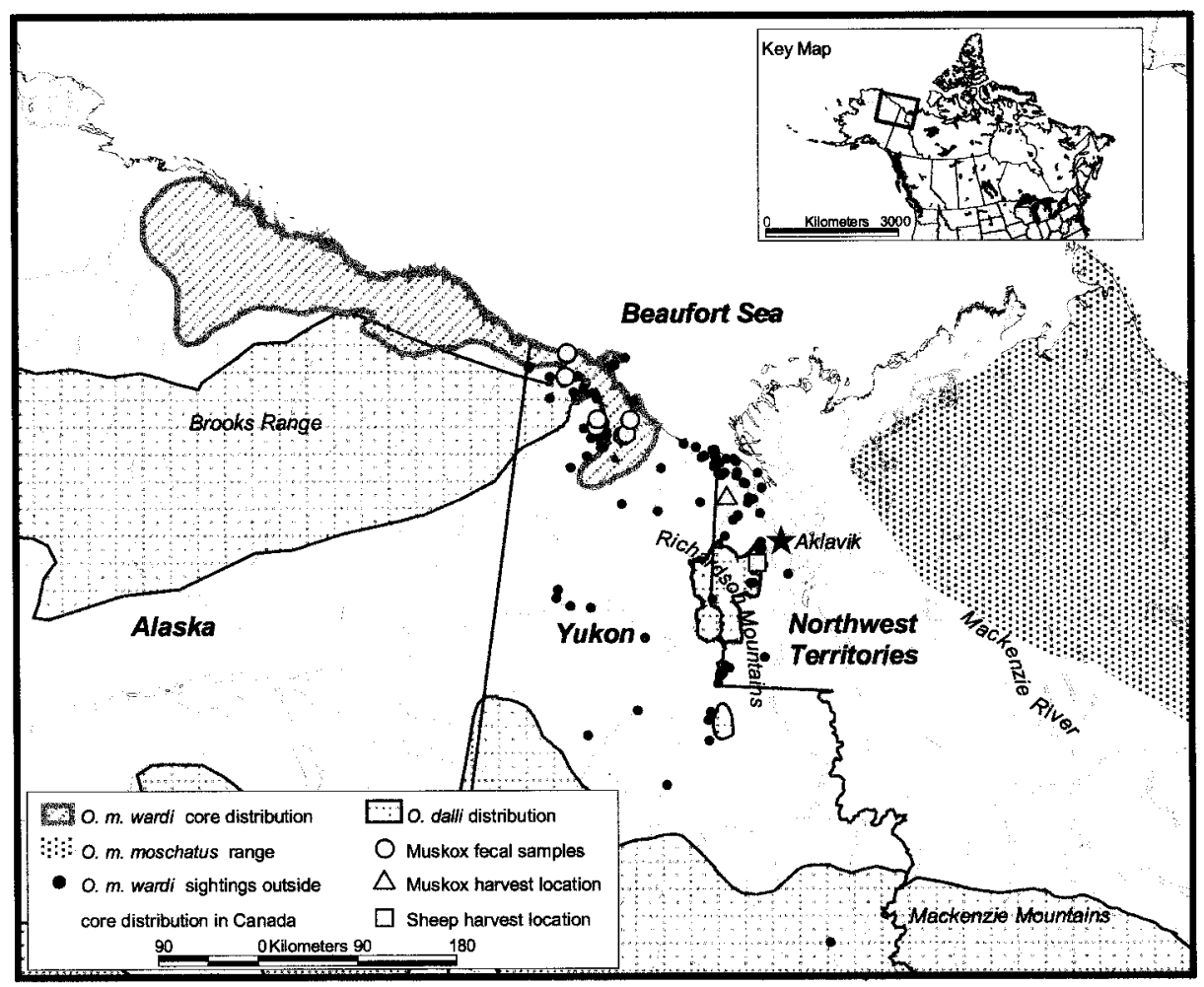

Figure 1. Geographic distributions of populations of muskoxen, including Ovibos moschatus wardi and $O$. moschatus moschatus, and Dall's sheep Ovis dalli dalli, along with localities of parasitological collections from the Northwest Territories and Yukon Territory, Canada.

O. moschatus wardi Lyddeker, 1900, which originated by sequential translocation of muskoxen from East Greenland to Nunivak Island, Alaska and subsequently to the Arctic Coastal Plain (Lent, 1999); recruitment on the Arctic Coastal Plain has been accompanied by a rapid range expansion eastward into northwestern Canada over the past decade (Reynolds, 1998). Among these muskoxen in North America, only Umingmakstrongylus pallikuukensis Hoberg, Polley, Gunn, and Nishi, 1995, is a characteristic component of the pulmonary helminth fauna and occurs in populations of $O$. moschatus moschatus on the mainland of the central Canadian Arctic (Hoberg et al., 1995; Kutz, 2000; Kutz, Hoberg, and Polley, 2001). Notably, there are no records of larvae or adults attributable to species of Protostrongylus Kamensky, 1905, in muskoxen throughout their Holarctic range (Boev, 1975; Alendal and Helle, 1983).

Documentation of the diversity of the northern protostrongylid fauna has often been ham- pered by the paucity of collections of adult nematodes that are required for definitive diagnosis (Kutz, Veitch et al., 2001) and lack of an ecosystem approach to survey and inventory, which can define the array of species that may circulate among sympatric bovid and cervid hosts (see also Brooks and Hoberg, 2000; Hoberg et al., 2001).

As a component of biodiversity assessment, we report results of surveys documenting distribution, identity, and new records for Protostrongylus sp. in $O$. moschatus wardi from the Yukon Territory (YT) and Northwest Territories (NT), Canada. Ecological context for the broader distribution of Protostrongylus sp. was gained through concurrent collections of Dall's sheep O. dalli dalli Nelson, 1884, from the Richardson Mountains, NT. These data provide a basis for exploring the role and influence of ecological isolation and host switching on parasite faunal diversity among muskoxen, Dall's sheep, and other ruminants in the Arctic. Additionally, we 
examine the potential for interchange of parasites between expanding populations of introduced $O$. moschatus wardi and native $O$. moschatus moschatus.

\section{Materials and Methods}

Studies designed to understand biodiversity and the interaction among protostrongylids and northern bovids were based on initial analyses of fecal samples. These were followed by strategic collections of hosts to determine the identity and distribution of parasites (e.g., Kutz, 2000; Kutz, Veitch et al., 2001).

\section{Collections from muskoxen}

Fecal specimens were collected in April 1999 directly from the recta of 10 adult $O$. moschatus wardi resident in the northwestern YT (in the area $68^{\circ} 58^{\prime} 28.92^{\prime \prime} \mathrm{N} ; 138^{\circ} 39^{\prime} 45.72^{\prime \prime} \mathrm{W}$ to $69^{\circ} 35^{\prime} 33.72^{\prime \prime} \mathrm{N}$; $140^{\circ} 08^{\prime} 15.72^{\prime \prime} \mathrm{W}$ ), which had been immobilized for placement of radio collars (Fig. 1). Specimens were frozen and subsequently shipped to the Western College of Veterinary Medicine, Saskatoon, Saskatchewan, Canada, for analysis. Protostrongylid larvae were recovered by standard techniques by use of the beakerBaermann method (Forrester and Lankester, 1997). Data from these analyses are reported as larvae per gram (LPG) of feces.

On 22 January 2000, 2 adult females and 3 calves near 9 mo of age from the Arctic Coastal Plain near Big Fish River, northwest of Aklavik, NT (ca. $68^{\circ} 33^{\prime} 33.6^{\prime \prime} \mathrm{N}$; $136^{\circ} 14^{\prime} 40.5^{\prime \prime} \mathrm{W}$ ), were harvested during a community hunt (Fig. 1). Necropsies were conducted in the field, with lungs frozen and transported to the laboratory at Inuvik, NT for detailed examination for lungworms. Fecal specimens taken at the time of collection revealed the adult muskoxen, but not calves, to have patent infections of protostrongylids, as indicated by first-stage larvae (L1s) of Protostrongylus sp. and unidentified dorsal-spined larvae (DSLs). Consequent$1 y$, calves were not studied in detail, and examinations focused on the female muskoxen specifically for collection of adult lungworms, following procedures outlined by Kutz, Veitch, et al. (2001). Specimens of adult Protostrongylus sp. were dissected from the pulmonary parenchyma, preserved in $70 \%$ ethanol and $5 \%$ glycerine, and later studied under differential interference contrast (Zeiss) as whole mounts cleared in phenol-alcohol or lacto-phenol.

\section{Collections from Dall's sheep}

We requested hunters in Aklavik, NT to collect and submit lungs, gastrointestinal tracts, and fecal samples from sheep harvested in the local area. Samples were later submitted from 3 sheep taken at Jurassic Butte in the northern Richardson Mountains (ca. $68^{\circ} 01^{\prime} 16.1^{\prime \prime} \mathrm{N}$; $\left.135^{\circ} 29^{\prime} 35.8^{\prime \prime} \mathrm{W}\right)$, southeast of Aklavik on 19 January 2000 (Fig. 1). The official place name is Jurassic Butte, and the local name is Black Mountain.

\section{Specimens examined}

The identity of specimens in $O$. moschatus wardi and Dall's sheep was confirmed on the basis of com- parison to the type series and vouchers of P. stilesi in the U.S. National Parasite Collection (USNPC), at the Parasite Biology, Epidemiology and Systematics Laboratory, Animal and Natural Resources Institute, Agricultural Research Service, USDA, Beltsville, Maryland, U.S.A.: (1) USNPC 29379 (types) and 75440 (from the original series) in bighorn sheep Ovis canadensis from Colorado, U.S.A.; (2) USNPC 45157 (vouchers) in O. canadensis from Jasper, Alberta, Canada; (3) USNPC 45160 in the mountain goat Oreamnos americanus (de Blainville, 1816), from Jasper, Alberta; (4) USNPC 49227 in O. canadensis from Wyoming, U.S.A.; (5) USNPC 86940 in $O$. dalli dalli from the Mackenzie Mountains, Northwest Territories; and (6) USNPC 90718 (University of Alaska Museum, UAFM 3580, 127, and 128), in $O$. dalli dalli from Dry Creek, Denali, Alaska, U.S.A. Additionally, we examined the types of Protostrongylus frosti Honess, 1942, USNPC 36852, in O. canadensis from Wyoming.

\section{Results}

Adult specimens of lungworms in 2 adult female muskoxen from the Arctic Coastal Plain and 3 Dall's sheep from the northern Richardson Mountains near Aklavik, NT (Fig. 1), were identified as $P$. stilesi. Voucher specimens were deposited in the USNPC as nos. 90715 and 90716 from $O$. moschatus wardi and 90717, 90813, and 90814 from $O$. dalli.

Nematodes in O. moschatus wardi and O. dal$l i$ were largely identical and were consistent with a series of known specimens including the types and those in $O$. dalli from the Alaska Range and the Mackenzie Mountains (Table 1). Male and female specimens were also in agreement with available descriptions, particularly with respect to the structure of the gubernaculum, including the complex capitulum and laterally expanded distal crura, and in the form of the provagina (Dikmans, 1931, 1943, 1957; Honess, 1942; Zdzitowiecki and Boev, 1971; Monson and Post, 1972). The gubernaculum unequivocally distinguishes $P$. stilesi from those species, Protostrongylus davtiani (Savina, 1940), P. frosti, Protostrongylus raillieti (Schulz, Orloff, and Kutass, 1933), and Protostrongylus rushi Dikmans, 1937, which, because of the biogeographic history of the Beringian region or host association, could be present in wild bovids from Alaska.

Measurements of most diagnostic characters were within the ranges previously established for this species. Relative to the original description and subsequent redescriptions, specimens in both $O$. moschatus wardi and $O$. dalli collected adjacent to Aklavik had slightly larger spicules, a 
Table 1. Morphometric data for adult males and females of Protostrongylus stilesi in muskoxen, Ovibos moschatus wardi, from the Arctic Coastal Plain and Dall's sheep, Ovis dalli dalli, from the Richardson Mountains; values in micrometers unless specified otherwise; $(n)$ with range followed by mean \pm 1 SD in parentheses.

\begin{tabular}{|c|c|c|}
\hline & Musk oxen & Dall's sheep \\
\hline \multicolumn{3}{|l|}{ Males } \\
\hline Number & 20 & 25 \\
\hline Body length (mm) & (2) $17.55-20.35$ & (2) $20.28-20.79$ \\
\hline Body width & (4) $109-120$ & (2) 79 \\
\hline Esophagus length & (6) $244-299(263 \pm 20.51)$ & (6) 239-271 (263 \pm 13.32$)$ \\
\hline Esophagus width (base) & (6) 36-47 (40.7 \pm 5.08$)$ & (6) $26-31(29 \pm 1.78)$ \\
\hline Esophagus \% body length & $1.3-1.4$ & $1.25-1.35$ \\
\hline Nerve ring* & - & - \\
\hline Excretory pore* & (4) $140-286(201 \pm 63.29)$ & (6) 273-309 (294 \pm 13.77$)$ \\
\hline Cervical papillae* & (4) 148-267 (201 \pm 50.82$)$ & (6) 286-307 (299 \pm 7.54$)$ \\
\hline Left spicule length & (14) 312-390 (367 \pm 21.39$)$ & (21) 330-434 (373 \pm 26.92$)$ \\
\hline Right spicule & (15) 299-397 (363 \pm 26.82$)$ & (21) 325-437 (371 \pm 28.87$)$ \\
\hline Gubernaculum length $\dagger$ & (14) $169-227(210 \pm 17.66)$ & (21) 175-231 $(206 \pm 13.96)$ \\
\hline Corpus length $\neq$ & (14) 91-137 (120 \pm 14.36$)$ & (21) 94-130 (112 \pm 11.02) \\
\hline Crura length & (16) $78-104(90 \pm 5.99)$ & (21) $81-101(94 \pm 5.25)$ \\
\hline Sickle-plate length & (10) $20-31(24 \pm 4.19)$ & (18) $18-26(21 \pm 2.3)$ \\
\hline Ventral plate (telamon) & (12) 78-118 (97 \pm 13.09$)$ & (20) $88-120(98 \pm 8.26)$ \\
\hline \multicolumn{3}{|l|}{ Females } \\
\hline Number & 3 partial & 2 partial \\
\hline Total length & - & - \\
\hline Tail length & (3) $74-77$ & (2) $94-101$ \\
\hline Vulva to anus & (3) $163-204$ & (2) $179-252$ \\
\hline Vulva to tail & (3) $237-281$ & (2) $273-353$ \\
\hline Provagina length & (2) $125-177$ & (2) $143-208$ \\
\hline Vagina length & (3) $370-459$ & (2) $322-536$ \\
\hline Sphincter length & (3) $56-82$ & (2) $65-104$ \\
\hline Egg length & (10) 89-140 (101 \pm 14.3$)$ & (5) 96-114 (103 \pm 7.4$)$ \\
\hline Egg width & (10) $44-62(53 \pm 5.3)$ & (5) 39-65 (47 \pm 9.4$)$ \\
\hline
\end{tabular}

consistently smaller gubernaculum, and larger eggs (Boev, 1975; Kutz, Veitch et al., 2001) (Table 1). There were no apparent differences in the proportions of the corpus or crura in material from $O$. canadensis and that in the present study. Spicule length for specimens in either muskoxen (using the left spicule as representative: $\bar{x}=367$ $\pm 21.4 \mu \mathrm{m})$ from the Arctic Coastal Plain or Dall's sheep $(\bar{x}=373 \pm 26.9)$ from the northern Richardson Mountains, was significantly greater (one-way ANOVA, $F=36.029, P<0.0001$ ) than that observed in populations of $P$. stilesi in Dall's sheep from the Alaska Range (Dry Creek, Denali) $(\bar{x}=292 \pm 1.33 \mu \mathrm{m})$ or in the Mackenzie Mountains $(\bar{x}=299 \pm 8.1)$.

Typical L1s of Protostrongylus found in Dall's sheep and muskoxen from the NT and YT were morphologically similar $(\bar{x}=368 \pm 22 \mu \mathrm{m}$ in total length for $10 \mathrm{~L} 1 \mathrm{~s}$ in muskoxen) and were considered to represent $P$. stilesi; these were also consistent with specimens in Dall's sheep from the Mackenzie Mountains $(\bar{x}=364 \pm 10 \mu \mathrm{m}$ in total length for $10 \mathrm{~L} 1 \mathrm{~s}$ ) (Kutz, Veitch et al., 2001). Near Aklavik, larval protostrongylids were found in both adult female muskoxen and included low numbers of $P$. stilesi (4-10 LPG) and DSLs ( $\sim 4-5$ LPG); larvae were not demonstrated in calves at $\sim 9$ mo of age. In the YT, fecal samples from 10 adult muskoxen all contained L1s presumed to be $P$. stilesi (4-78 LPG, $\bar{x}=33$ ) and DSLs (2-69 LPG, $\bar{x}=16$ ). The identity of the DSLs was undetermined, although they were morphologically inconsistent with DSLs of Umingmakstrongylus (cf. Hoberg et al., 1995).

All adult nematodes were found in the parenchyma, and lesions associated with $P$. stilesi in adult muskoxen were located in the caudodorsal 
and diaphragmatic surface of the diaphragmatic lobes. The lesions were tan to red-brown, round to oval, $\sim 3-5 \mathrm{~mm}$ in diameter, extended into the pulmonary parenchyma, and contained adult nematodes, eggs, and larvae. Adult parasites were confined to the alveolar parenchyma and were surrounded by a mild to focally marked cellular infiltrate consisting primarily of lymphocytes and a few macrophages (T. Bollinger, unpublished observations). Gross lesions in the lungs of muskoxen and Dall's sheep from both the Richardson and Mackenzie mountains were similar (Kutz, Veitch et al., 2001).

\section{Discussion}

During the current study, specimens of $P$. stilesi were found for the first time in a population of introduced muskoxen (O. moschatus wardi) from YT and NT and in Dall's sheep from the Richardson Mountains, NT. Parasites in sympatric muskoxen and Dall's sheep were morphologically indistinguishable, which suggests that they represent a single population distributed between these caprine hosts. The occurrence of $P$. stilesi in muskoxen has both basic and applied significance, serves as a basis for discussion of host specificity and host switching, and has some management implications for parasites in muskoxen.

\section{A context for Protostrongylidae and Protostrongylus in musk oxen}

Prior to the current study, there have been no records of larvae or adults attributable to species of Protostrongylus in muskoxen. Although lungworms (Protostrongylidae) are uncommon parasites in $O$. moschatus, sampling effort has been sufficient to demonstrate the occurrence of a number of protostrongylids in muskoxen across the Holarctic. Umingmakstrongylus pallikuukensis Hoberg, Polley, Gunn, and Nishi, 1995, is the only characteristic component of the pulmonary helminth fauna in O. moschatus moschatus (Hoberg et al., 1995; Kutz, Hoberg, and Polley, 2001). Elsewhere in the Nearctic, DSLs of protostrongylids, distinct from those of $U$. pallikuukensis, were observed during the present study in $O$. moschatus wardi and sporadically in fecal collections from native $O$. moschatus moschatus at mainland localities across the westcentral Canadian Arctic (S. J. Kutz, unpublished data). Among $O$. moschatus wardi introduced from East Greenland to Alaska, DSLs presumed to be a species of Muellerius Cameron, 1927, were reported on Nunivak Island (Dau, 1981); the identification is now considered to be in error (Kutz, Veitch et al., 2001). Additionally, in muskoxen that were introduced from Greenland to Scandinavia, DSLs may represent species of Varestrongylus Bhaelerao, 1932, or Elaphostrongylus Cameron, 1931, acquired from cervids or protostrongylids such as Cystocaulus Schulz, Orlov, and Kutass, 1933, that are typical in domestic sheep Ovis aries Linnaeus, 1758 (Alendal and Helle, 1983; Holt et al., 1990; Stéen et al., 1994).

Notably, Protostrongylus sp. or P. stilesi has not been observed in East Greenland or in any populations of $O$. moschatus wardi that have been established from this or related sourcese.g., Norway; Svalbard, Sweden; Nunivak Island, Alaska; and the Taimyr Peninsula, Russia (Bos, 1967; reviewed in Allendal and Helle, 1983; Hoberg et al., 1995). Thus, the occurrence of $P$. stilesi, otherwise a parasite characteristic of Ovis spp. in the Nearctic, is not linked to translocation of previously infected muskoxen from Nunivak Island to the Arctic Coastal Plain (for a history of translocations and introductions, see Lent, 1999).

\section{Range and morphological variation of $P$. stilesi in Dall's sheep}

A new geographic record and identification of this protostrongylid from the Richardson Mountains implies a broad distribution for $P$. stilesi in O. dalli (Kutz, Veitch et al., 2001). First stage larvae, presumed to be $P$. stilesi, have been found in Dall's sheep from the central Alaska Range (Goble and Murie, 1942), the Brooks Range, the Mackenzie Mountains, and the Richardson Mountains (Kutz, Veitch et al., 2001). There have been few definitive identifications, and only recently have records been published of adult $P$. stilesi from localities in Alaska (Dry Creek, near Denali) and NT (Mackenzie Mountains) (Kutz, Veitch et al., 2001).

Among Dall's sheep, hosts and parasites appear to occupy a series of disjunct ranges, and as such may be indicated by morphological variation for some characters in $P$. stilesi. Discrete variation in spicule length was observed between $P$. stilesi in muskoxen on the Arctic Coastal Plain and Dall's sheep from the Richardson Mountains, and in sheep from the Mackenzie Mountains and Alaska Range, on the ba- 
sis of comparisons during the present study. This may be consistent with highly isolated populations of $P$. stilesi in Dall's sheep, a history of range fragmentation, and limited contemporary gene flow for parasites and hosts. Comparisons of these putative populations and an evaluation of this hypothesis are currently being conducted on the basis of molecular analyses.

\section{$P$. stilesi in muskoxen and Dall's sheep}

As has been documented above, P. stilesi, a typical lungworm in wild thin-horned sheep at Arctic and Subarctic latitudes in the Nearctic (Kutz, Veitch et al., 2001), had not been reported previously in $O$. moschatus. It cannot be excluded, however, that other species of Protostrongylus could be present in Alaska, NT, and YT. On the basis of the present study, protostrongylids, including $P$. stilesi, appear to be common and widespread in $O$. moschatus wardi from YT and western NT; the protostrongylid fauna in muskoxen from Alaska is unknown. Additionally, $P$. stilesi does not appear to be present in O. moschatus moschatus from eastern and central NT and Nunavut, on the basis of extensive examinations of lungs and fecal samples that have been conducted in surveys for $U$. pallikuukensis (e.g., Hoberg et al., 1995; Kutz, 2000; Kutz, Hoberg and Polley, 2001).

The occurrence of $P$. stilesi in a population of introduced muskoxen is indicative of a contemporary colonization event from Dall's sheep. The morphological uniformity of specimens from the Arctic Coastal Plain and the Richardson Mountains is consistent with this contention but would not refute the possibility of an already broader distribution for $P$. stilesi in muskoxen north of the Brooks Range in Alaska. On the basis of the documented distribution of protostrongylids in members of Caprini and Ovibos (Boev, 1975; Alendal and Helle, 1983; Hoberg et al., 1995; Carreno and Hoberg, 1999; Kutz, 2000), however, it is evident that Protostrongylus was not derived from Nunivak Island or from East Greenland with the original translocation of O. moschatus wardi.

Data are compatible with acquisition of $P$. stilesi by muskoxen in contact with thin-horned sheep, which are the typical and well-established hosts in YT, NT, and Alaska. Such host switching could have accompanied the contact among muskoxen and Dall's sheep in the Brooks Range after their initial introduction to the Arctic
Coastal Plain or may be a more recent event coincidental with contact in the region of the Richardson Mountains (Fig. 1). Strategic collections in Alaska to establish the identity of Protostrongylus sp. in Dall's sheep and any potential occurrence in $O$. moschatus wardi are necessary to evaluate these alternative hypotheses regarding distribution.

\section{Host specificity, host switching, and ecological isolation for $\boldsymbol{P}$. stilesi}

Host specificity has both historical/phylogenetic and ecological/contingent components, and the interaction of these determinants influences the ultimate host distribution of a given parasite species (e.g., Poulin, 1998). Interestingly, muskoxen appear to acquire parasites when in sympatry with source populations of bovid or cervid hosts (reviewed by Alendal and Helle, 1983), which suggests that, for $O$. moschatus, the barriers to infection by helminths may be primarily ecological, as opposed to physiological (see also Lent, 1999). Ecological isolating mechanisms may constitute the basis for limitations in host distribution for some parasites, which indicates that narrow host specificity can be contextual. The observed distribution of $P$. stilesi in wild sheep (e.g., in bighorn sheep $O$. canadensis and thin-horned sheep $O$. dalli ssp.) (Becklund and Senger, 1967) and, less often, mountain goats Oreamnos americanus (Boddicker et al., 1971), across its range in the Nearctic may indicate a level of specificity that is more apparent than real. Thus, the potential for host switching among some bovids could be limited currently by isolation and habitat segregation. Such may be consistent with reports of this protostrongylid in $O$. americanus when it is in contact with $O$. canadensis (Boddicker et al., 1971).

In a contemporary context, colonization of muskoxen by parasites may be a predictable event in zones of sympatry with Dall's sheep (Fig. 1). The core distribution for O. moschatus wardi on the Arctic Coastal Plain is, to some degree, parapatric to that of $O$. dalli in the eastern Brooks Range and areas of the Richardson Mountains. Radio-collared muskoxen, which are known to be infected with Protostrongylus, appear to be in sympatry, or at a minimum seasonally occupy common range, with Dall's sheep in this region (Fig. 1). It appears probable that muskoxen are exposed to infection during the summer, when herds move into higher coun- 
try to escape insects and occupy the winter ranges of Dall's sheep. Maintenance of sympatry in zones of contact may be critical for host switching from Dall's sheep to muskoxen, but it is not known whether viable populations and transmission of $P$. stilesi can be maintained in the absence of $O$. dalli. Notably, the distribution of $P$. stilesi in muskoxen in the YT and NT (Fig. 1) suggests that this bovid could be a mediator for dispersal and, thus, gene flow among otherwise isolated populations of parasites in Dall's sheep from the eastern Brooks Range and northern Richardson Mountains.

In a historical context, during the Pleistocene, sympatry within an assemblage of large ungulates, including wild sheep and muskoxen, was probably more extensive than it is at present (Guthrie, 1982, 1984; Vereshchagin and Baryshnikov, 1982). The existence of a Pleistocene megafauna, characterized by extensive sympatry and high diversity, indicates the potential for colonization by parasites among ecologically similar hosts (Hoberg et al., 1995, 1999). Climatological fluctuations and habitat perturbation at the termination of the Pleistocene led to range restriction and diminished sympatry and may have been a contributing factor in extinction for some species of the mammalian community. A pattern of increasing allopatry during the Holocene may have been a driver for alteration in structure for parasite faunas: (1) lower parasite faunal diversity in some host groups, (2) postglacial isolation, as a determinant of divergence in parasite populations; and (3) apparent specificity for some parasites that is currently maintained by altitudinal or latitudinal restrictions on the ranges of contemporary populations of ungulates. These factors reinforce recognition of the role of ecological isolating mechanisms as determinants of the distribution and historical and contemporary structure of parasite faunas in northern ruminants (Hoberg et al., 1999).

Disruption of contemporary ecological isolating barriers can result from habitat perturbation, either anthropogenically or climatologically driven, and from management practices that influence the distribution of ungulate hosts (Hoberg, 1997; Daszak et al., 2000). Climate change may drive habitat alteration that leads to shifting distributions, range expansion, and more extensive seasonal overlap among species that are segregated by seasonal effects, altitude, or latitude-i.e., the concept of a breakdown in iso- lating mechanisms and the generation of interfaces that drive host switching (Hoberg, 1997). Consequently, if zones of contact become more extensive or the temporal limit on allopatry is relaxed, we may observe increasing instances of host switching by parasites or pathogens at the interface of newly emerging ecotones. Such a prediction relates to apparent specificity that is maintained ecologically for a diversity of helminth parasites. For example, both $P$. stilesi in musk oxen, which is derived from contact with $O$. dalli, and the abomasal nematode Ostertagia gruehneri Skrjabin, 1929, in Dall's sheep (E. P. Hoberg, S. J. Kutz, and A. Veitch, unpublished data), derived from caribou Rangifer tarandus (Linnaeus, 1758), would be in this category (Hoberg et al., 2001).

\section{Parasites in introduced and native muskoxen}

The recent expansion of the populations of $O$. moschatus wardi on the mainland, which has resulted in range overlap with Dall's sheep in the Richardson Mountains, is also expected to lead to new contact zones for native and introduced muskoxen that could further influence parasite distribution. Muskoxen (i.e., O. moschatus wardi) originally introduced to Alaska from East Greenland have rapidly occupied habitat on the Arctic Coastal Plain (Reynolds, 1998; Lent, 1999), with an eastward range expansion that now includes the Richardson and northern Mackenzie mountains and the outer Mackenzie River Delta (Veitch et al., 2000; J. Nagy, unpublished observations) (Fig. 1). Concurrently, native muskoxen (i.e., O. moschatus moschatus) from the population on the east-central mainland of NT have been dispersing westward from their core range (Veitch, 1997; Fournier and Gunn, 1998). It is currently unknown whether these populations have developed a contact zone, although their distributions may now be limited by the Mackenzie River.

As has been documented in the current study, $P$. stilesi is a common parasite in $O$. moschatus wardi, at a minimum across a limited zone in the northern Richardson Mountains and on the eastern region of the Arctic Coastal Plain (Fig. 1) but is unknown in O. moschatus moschatus. In contrast, $U$. pallikuukensis is prevalent in $O$. moschatus moschatus, has a distribution currently limited to the region east of the Mackenzie River, and has not been observed in $O$. mos- 
chatus wardi (Kutz, 2000; Kutz, Hoberg, and Polley, 2001). Consequently, there are management implications with respect to the potential for exchange of protostrongylids as well as other macro- and microparasites between these expanding populations (Hoberg, 1997), given the apparent nature of ecological controls on the distribution of helminths in muskoxen.

Alteration in complex host-parasite systems in the north that may be linked to climatologically and anthropogenically driven global change and the effects of management must be tracked within the context of biodiversity survey and inventory and programs to develop archival collections as the foundation for monitoring ecosystem-level perturbations (Brooks and Hoberg, 2000). The current developing interface for native and introduced muskoxen, wild sheep, and parasites along the Mackenzie River ecotone represents a potential natural model and field laboratory in which to explore the interaction of parasites and naive host populations in the prevailing regime of environmental change. Practical benefits are gained in defining the role of parasites and parasitism as factors that influence population health among northern ruminants. Such unique systems also constitute meaningful baselines for examining dynamic interfaces for host-parasite assemblages and a means to elucidate critical data for understanding the primary limiting factors that control parasite distribution, transmission, faunal structure, and patterns of emerging disease (Hoberg, 1997; Brooks and Hoberg, 2000).

\section{Acknowledgments}

The studies reported herein are a contribution from the Research Group for Arctic Parasitology, centered at the University of Saskatchewan, and the Beringian Coevolution Project at Idaho State University. Comparative specimens were provided by Joseph Cook and Amy Runck from collections at the University of Alaska Museum, Fairbanks. Pathology reports were provided by Trent Bollinger from the Canadian Co-operative Wildlife Health Center, Western College of Veterinary Medicine, Saskatoon. Brent Wagner conducted or assisted with procedures for recovery of larval parasites at the Department of Veterinary Microbiology, Western College of Veterinary Medicine. Ian McLeod, Department of Resources, Wildlife and Economic Development (DRWED), Aklavik, NT, assisted with the com- munity hunt and collection of samples from musk oxen and Dall's sheep. Wendy Wright of DRWED, Inuvik, NT, prepared the distribution maps. We sincerely thank the Aklavik Hunters and Trappers Committee, Aklavik, NT, for their contributions to these studies. Research was supported in part by the Department of Resources, Wildlife and Economic Development, and Inuvialuit Land Claim Implementation Funds, Yukon Territorial Government, and the National Science Foundation, Division of Environmental Biology, Biotic Surveys and Inventories 9972154.

\section{Literature Cited}

Alendal, E., and O. Helle. 1983. Helminth parasites of muskoxen Ovibos moschatus in Norway incl. Spitsbergen and in Sweden, with a synopsis of parasites reported from this host. Fauna Norvegica, Series A 4:41-52.

Becklund, W. W., and C. M. Senger. 1967. Parasites of Ovis canadensis in Montana, with a checklist of the internal and external parasites of the Rocky Mountain bighorn sheep in North America. Journal of Parasitology 53:57-165.

Boddicker, M. L., E. J. Hugghins, and A. H. Richardson. 1971. Parasites and pesticide residues of mountain goats in South Dakota. Journal of Wildlife Management 35:94-103.

Boev, S. N. 1975. Protostrongylids. Fundamentals of Nematodology, Vol. 25. Helminthological Laboratory, Academy of Sciences of the U.S.S.R., Moscow, Russia. (English translation, 1984. U.S. Department of Agriculture, Washington, D.C., U.S.A., and Amerind Publishing Co., New Delhi, India, $337 \mathrm{pp}$.

Bos, G. N. 1967. Range types and their untilization by muskox on Nunivak Island, Alaska: a reconnaissance study. MSc. Thesis, University of Alaska, Fairbanks, Alaska, U.S.A. 113 pp.

Brooks, D. R., and E. P. Hoberg. 2000. Triage for the biosphere: the need and rationale for taxonomic inventories and phylogenetic studies of parasites. Comparative Parasitology 67:1-27.

Carreno, R., and E. P. Hoberg. 1999. Evolutionary relationships among the Protostrongylidae (Nematoda: Metastrongyloidea) as inferred from morphological characters, with consideration of parasite-host coevolution. Journal of Parasitology 85: 638-648.

Daszak, P., A. A. Cunningham, and A. D. Hyatt. 2000. Emerging infectious diseases of wildlifethreats to biodiversity and human health. Science 287:443-449.

Dau, J. 1981. Protostongylus, Muellerius and Dictyocaulus. Pages 141-146 in R. A. Dieterich, ed. Alaskan Wildlife Diseases. University of Alaska, Fairbanks, Alaska, U.S.A.

Dikmans, G. 1931. Two new lungworms from North America ruminants and a note on the lungworms 
of sheep in the United States. Proceedings of the United States National Museum 79:1-4.

- 1943. The lungworm, Protostrongylus rushi Dikmans, 1937, of the mountain sheep, Ovis canadensis. Proceedings of the Helminthological Society of Washington 10:8-9.

-1957. A note on the specific identity of Protostrongylus frosti Honess, 1942. Proceedings of the Helminthological Society of Washington 24: 116-120.

Forrester, S. G., and M. W. Lankester. 1997. Extracting protostrongylid nematode larvae from ungulate feces. Journal of Wildlife Diseases 33:511516.

Fournier, B., and A. Gunn. 1998. Muskox numbers and distribution in the Northwest Territories, 1997. Department of Resources, Wildlife and Economic Development, Government of the Northwest Territories, Yellowknife, NT. File Report No. 121. $55 \mathrm{pp}$

Goble, F. C., and A. Murie. 1942. A record of lungworm in Ovis dalli (Nelson). Journal of Mammalogy 23:220-221.

Guthrie, D. 1982. Mammals of the mammoth steppe as paleoenvironmental indicators. Pages 307-326 in D. M. Hopkins, J. V. Matthews Jr., C. E. Schweger, and S. B. Young, eds. Paleoecology of Beringia. Academic Press, New York, New York, U.S.A.

- 1984. Mosaics, allelochemics and nutrients: an ecological theory of late Pleistocene megafaunal extinctions. Pages 259-298 in P. S. Martin and R. G. Klein, eds. Quaternary Extinctions: A Prehistoric Revolution. University of Arizona Press, Tucson, Arizona, U.S.A.

Hoberg, E. P. 1997. Parasite biodiversity and emerging pathogens: a role for systematics in limiting the impacts on genetic resources. Pages 71-83 in K. E. Hoagland and A. Y. Rossman, eds. Global Genetic Resources: Access, Ownership and Intellectual Property Rights. Association of Systematics Collections, Washington, D.C., U.S.A.

$\longrightarrow$, A. Kocan, and L. G. Rickard. 2001. Gastrointestinal strongyles in wild ruminants. Pages 193-227 in W. Samuel, M. Pybus, and A. Kocan, eds. Parasitic Diseases of Wild Mammals. Iowa State University Press, Ames, Iowa, U.S.A.

$\longrightarrow$, K. J. Monsen, S. Kutz, and M. S. Blouin. 1999. Structure, biodiversity, and historical biogeography of nematode faunas in Holarctic ruminants: morphological and molecular diagnoses for Teladorsagia boreoarcticus $\mathrm{n}$. sp. (Nematoda: Ostertagiinae), a dimorphic cryptic species in muskoxen (Ovibos moschatus). Journal of Parasitology 85:910-934.

, L. Polley, A. Gunn, and J. S. Nishi. 1995. Umingmakstrongylus pallikuukensis gen. nov. et sp. nov. (Nematoda: Protostrongylidae) from muskoxen, Ovibos moschatus, in the central Canadian Arctic, with comments on biology and biogeog- raphy. Canadian Journal of Zoology 73:22662282.

Holt, G., C. Berg, and A. Haugen. 1990. Nematode related spinal myelomeningitis and posterior ataxia in muskoxen (Ovibos moschatus). Journal of Wildlife Diseases 26:528-531.

Honess, R. F. 1942. Lungworms of domestic sheep and bighorn sheep in Wyoming. Agricultural Experiment Station, University of Wyoming, Laramie, Bulletin 255:3-24.

Kutz, S. J. 2000. The biology of Umingmakstrongylus pallikuukensis, a lung nematode of muskoxen in the Canadian Arctic: Field and laboratory studies. Doctoral Dissertation, University of Saskatchewan, Saskatoon, Saskatchewan, Canada. 190 pp. , E. P. Hoberg, and L. Polley. 2001. A new lungworm in muskoxen: an exploration in arctic parasitology. Trends in Parasitology 17:276-280.

, A. M. Veitch, E. P. Hoberg, B. T. Elkin, E. J. Jenkins, and L. Polley. 2001. New host and geographic records for Protostrongylus stilesi and Parelaphostrongylus odocoilei (Protostrongylidae) in Dall's Sheep (Ovis dalli dalli) from the Mackenzie Mountains, Northwest Territories, Canada. Journal of Wildlife Diseases 37:761-774.

Lent, P. C. 1999. Muskoxen and Their Hunters. University of Oklahoma Press, Norman, Oklahoma, U.S.A. 324 pp.

Monson, R. A., and G. Post. 1972. Experimental transmission of Protostrongylus stilesi to bighornmouflon sheep hybrids. Journal of Parasitology 58:29-33.

Poulin, R. 1998. Evolutionary Ecology of Parasites. Chapman and Hall, London, U.K. 212 pp.

Reynolds, P. E. 1998. Dynamics and range expansion of a reestablished muskox population. Journal of Wildlife Management 62:734-744.

Stéen, M., S. Persson, and L. Hajdu. 1994. Protostrongylidae in Cervidae and Ovibos moschatus: a clustering based on isoelectric focusing on nematode proteins. Applied Parasitology 35:193-206.

Veitch, A. M. 1997. An aerial survey for muskoxen in the northern Sahtu Settlement Area, March 1997. Manuscript Report No. 103. Department of Resources, Wildlife and Economic Development, Norman Wells, Northwest Territories. 42 pp.

, E. N. Simmons, J. Adamczewski, and R. Popko. 2000. Status, harvest and comanagement of Dall's sheep in the Mackenzie Mountains, Northwest Territories. Northern Wild Sheep and Goat Council 11:134-153.

Vereshchagin, N. K., and G. F. Baryshnikov. 1982. Paleoecology of the mammoth fauna in the Eurasian Arctic. Pages 267-269 in D. M. Hopkins, J. V. Matthews Jr., C. E. Schweger, and S. B. Young, eds. Paleoecology of Beringia. Academic Press, New York, New York, U.S.A.

Zdzitowiecki, K., and S. N. Boev. 1971. Remarks on the classification and morphology of the nematodes of the subgenus Davtianostrongylus Boev, 1950, with a description of a new species. Acta Parasitologica Polonica 19:237-246. 